\title{
„Nu cerceta aceste legi că ești prea prost să le-nțelegi”. Despre justificarea normei
}

\author{
conf. univ. dr. Radu Rizoiu \\ Facultatea de Drept, Universitatea București \\ Motto: The ultimate in vanity \\ Exploiting their supremacy \\ I can't believe the things you say \\ (Metallica, ... and Justice for All)
}

Rezumat: Articolul analizează recentele măsuri luate de Guvern prin redactarea de reguli noi vizând restrângerea libertății individuale din cauza crizei sanitare fără a oferi o justificare corespunzătoare cu privire la necesitatea unor măsuri atât de restrictive. Mai degrabă decât a releva o abordare paternalistă, aceste practici sugerează o lipsă de fundamentare a măsurilor chiar la nivelul Guvernului, ceea ce a ridicat problema unei copieri a măsurilor luate de alte state europene. Articolul propune ca teză principală ca, în special în aceste perioade încărcate de emoții, Guvernul să explice pe larg rațiunile pentru care a adoptat anumite reguli.

Cuvinte-cheie: reguli, justificarea regulii, urgență

\section{„Do not look into these laws 'cause you are too stupid to perceive them". On the reasoning of the rule}

Abstract: The paper looks in to the recent practices of the Government to release new regulations limiting the individual freedom due to pandemic situation without a proper justification of the need of such harsh measures. Rather than being a paternalistic approach, the practice suggested that the Government is itself unable to explain why it took such action being believed that it preferred to copy/paste the restrictions enacted in other European countries. The thesis proposed by the paper is that (especially in these emotional periods) the Government is required to explain to the public the reason behind the rules it adopts.

Keywords: rules, reasoning behind the rule, emergency

Sunt două povestiri ale lui Richard Matheson care oferă două perspective interesante cu privire la izolare. Prima dintre acestea, „Născut din bărbat și femeie” spune povestea unei ființe (umane?) care este sechestrată de părinții săi naturali pentru a nu putea avea contact cu restul oamenilor. Interesant este faptul că ființa sechestrată nu își condamnă ,gardienii”, ci încearcă să găsească explicații bazate pe premisa unor decizii raționale luate de către aceștia. Din păcate, rațiunile pe care el le găsește nu sunt neapărat cele pe care părinții le avuseseră în vedere... În „Sunt o legendă”, izolarea este cauzată de o epidemie. Clișeele în care a eșuat adaptarea cinematografică („,I Am Legend”) din 2007 cu Will Smith în rolul titular nu sunt vina cărţii, care este mult mai subtilă. Epidemia îl izolează pe erou în mijlocul unui oraș populat cu... zombi. El este singurul supraviețuitor al „,infecției” și caută cu disperare să găsească alți supraviețuitori. În această epopee, este ajutat de o rutină care îi permite să ị̂i continue viața. Speranța este ceea ce îi dă puterea de a continua. Exact acea speranță care dispare în „Ultimul țărm” („On the Beach”), romanul distopic al lui Nevil Shute. Exact acea speranță care îl face pe eroul povestirii „Coasa” (,Scythe”) a lui Ray Bradbury să nu se mai gândească la semenii săi.

De ce am evocat aceste texte? Pentru că ele ne arată modul în care regulile ne pot ajuta să trecem (mai ușor) peste situații limită. În primul rând, regulile trebuie înțelese atât în ceea ce spun, 
cât (mai ales) în ceea ce privește scopul pentru care impun o anumită conduită. Regulile pe care ni le definim singuri sunt cel mai uşor de acceptat pentru că au o internalizare ontologică. Regulile sunt, de regula (!), impuse din afara noastră de alte persoane sau structuri. Aceste reguli trebuie să fie nu numai știute, ci și înțelese. Ceea ce face actualmente statul, atunci când prezintă noile reglementări pe toate canalele de transmisie mediatică, satisface doar prima cerință: cunoașterea legii. Ele omit însă cea de-a doua componentă care este cel puțin la fel de importantă: explicarea regulii.

Ne aducem aminte din copilărie argumentul de tip „bully”: „Trebuie să faci așa pentru că așa spun eu și eu sunt mare, iar tu ești mic și nu poți face nimic în privința asta". În mod special am folosit o exprimare culeasă dintr-o carte de copii (Robert Dahl, Matilda), pentru a oferi o pastișă îngroșată unor atitudini care pot fi extrem de sofisticate în a ascunde filonul autoritarist. Am ales să nu mă refer la acest argument ca fiind unul de autoritate (deși în teoria erorilor de raţionament el acolo este plasat) pentru că nu vreau să subminez tocmai ideea de autoritate (Hannah Arendt a explicat importanța autorității, chiar dacă a remarcat la mijlocul secolului trecut că ideea de autoritate s-a rarefiat foarte mult astăzi). Încă din perioada Iluminismului, legea se pretinde a fi produsul rațiunii (umane). Prin urmare, ea are aura unei soluții raționale la o problemă reală. Legea este răspunsul pe care societatea îl dă unei probleme care afectează (sau riscă să afecteze) propria sa urzeală. Evident că această construcție își arată și limitele: de vreme ce legea este menită să apere societatea, înseamnă că ea este ontologic conservatoare. Ea va tinde să apere un anumit cadru social considerat dezirabil. În aceste limite însă se consideră că răspunsul legislativ trebuie să fie concluzia unui silogism care pornește de la un set de principii (ca premisă majoră) pe care le aplică la problema de rezolvat (ca premisă minoră). Iar rezultatul silogismului trebuie să urmeze regulile logicii (nu o să complic situația pentru a explica ce tip de logică - unii spun formală, alţii deontică).

Prin urmare, atunci când regula vine din exterior (de la Stat), ea are nevoie de o explicaţie pentru a fi impusă destinatarilor. Precum un virus, legea este menită să se propage în cadrul populației. Idealul oricărui legiuitor este ca legea să fie cunoscută de toată lumea, adică să fie un virus cu o capacitate de infecție de $100 \%$ din populație. Pentru a face asta, legea trebuie să se „atașeze” la fiecare individ. Ea folosește o serie de „enzime” precum convingerea și sancțiunea pentru a intra în conștiința individului și a o „,infecta”. La majoritatea indivizilor funcționează convingerea transformată în înțelegerea faptului că respectarea legii este calea justă (corectă, ca la Rawls, sau utilă, ca la Mills, după caz) de a comporta în societate. Dar în toate situațiile, convingerea are nevoie de argumente. Iar argumentul „,respectă legea pentru că așa am zis eu” este cel mai jalnic dintre argumente (de aceea teza pozitiviștilor potrivit cărora legea este cea edictată de o anumită ,,autoritate” este criticabilă). Da, putem ,îmbrăca” acest argument în podoabe retorice extrem de sofisticate (cel mai interesant mi s-a părut cel al lui Habermas care ne spune că legea reprezintă un soi de înțelepciune populară care decantează dorințele majorității organizate în instituții, dar problema rămâne cea a lipsei unui argument rațional), dar rămânem la problema hainelor (celor „,noi” ale) împăratului.

Pentru a convinge (cu adevărat) pe cineva trebuie să îi explici de ce este bine (just sau util, în funcție de sistemul de valori ales) să facă ceea ce își dorești tu să facă. Și aici sistemul nostru normativ nu este pregătit. Rămas oarecum încremenit în epoca unui paternalism specific comunismului, legea care oferă indicații pentru legiuitor cum să scrie un text normativ spune că legiuitorul nu trebuie să-și justifice soluția. Altfel spus, el trebuie să găsească soluția și apoi să ,împrăștie lumina” către populație fără a spune cum a produs-o. Or, îndemnul „faceți cum spunem noi și (vă) va fi bine" devine extrem de neconvingător tocmai în vremuri de criză, atunci când legea ar trebui să aibă forța de convingere maximă. Ce vedem azi? Guvernul spune să stăm în casă pentru că așa este bine, iar omul care stă cu toată familia și copiii într-un apartament modest vede 
că i-a scăzut dramatic și bruma de calitate a vieții pe care o avea până atunci. Și atunci caută o explicație, iar „soluțiile” oferite de variatele teorii ale conspirației par mult mai digerabile decât lipsa oricărei explicații. Își construiește un univers (concentrațional?) în care umbrele unor argumente devin veritabile rațiuni universale. Precum creatura din povestirea lui Matheson, își făurește un univers normativ propriu. Acest univers se dovedește însă la fel de departe de realitate precum umbrele din peștera lui Platon.

Riscul este acela că neînțelegerea unei norme (și mai ales construirea unei explicații proprii) poate conduce la nesocotirea normei. Am văzut în ultimele zile multiple cazuri în care aplicarea unor amenzi ridicate (apropo, majorarea sancțiunilor printr-o procedură urgentă ridică probleme juridice complicate) nu au fost suficiente pentru a asigura respectarea legii. Sancțiunea trebuie să rămână un ultim mijloc în aplicarea legii. Ea este destinată mai degrabă celor care oricum ignoră rațiunea legii și este menită să le ofere un ,argument” pe care îl înțeleg (iar dacă nu îl înțeleg, măcar să fie izolați de masa populației). Da atunci când rațiunea legii se vede abia când este aplicată sancțiunea, s-ar putea să fie prea târziu. Precum în povestirea lui Bradbury, omul poate ajunge la nivelul de disperare la care nicio o încălcare ulterioară a legii nu mai contează pentru el.

Justificarea unei norme este ,periculoasă” în momentul în care devoalează breșele din raționamentul (imperfect) care a generat-o. Iar celebrele conferințe de presă din serile de weekend în care ne sunt anunțate (inclusiv prin limbajul semnelor) noile restricții ce se vor aplica în următoarea săptămână (am ajuns să măsurăm această criză cu săptămâna, punctat de ordonanțele militare) nu ajută la explicarea măsurilor luate. Simpla citire a unor reguli nu este suficientă. Mai ales atunci când cuvintele se dovedesc atât de înșelătoare. Cu toții ne amintim acea conferință în care ministrul anunța o serie de ,recomandări”, iar subordonatul său simțea nevoia să spună că ele sunt de fapt obligații (ceea ce au și devenit după câteva zile). Dar poate că adjectivul „militar” poate oferi o explicație. Cu toții ne amintim filmele americane (de la comedii ușoare până la excelentul „,Full Metal Jacket”) în care instrucția militară de bază pare a avea un singur rol: spălarea pe creier a recruților pentru a asculta orbește ordinele fără să le analizeze justețea.

Pe de altă parte, Guvernul a înțeles necesitatea explicării unor măsuri, iar noile ordonanțe de urgenţă au început să aibă o parte de justificare din ce în ce mai extinsă în preambulul actului normativ. Vedem cum modelul de la Bruxelles se extinde în tehnica de reglementare autohtonă: uneori preambulul este mai util în înțelegerea reglementării decât normele însele (care, scoase din context, sună inept). Iată cum virtuţile explicaţiei ajung să fie utile chiar și pentru autoritatea legiuitorului. Chiar și modificările frecvente ale acestor măsuri (deși criticabile și criticate intens în aceste zile) îmi apar ca recunoașteri ale limitelor cunoașterii umane (iar legiuitorul este și el tot om) și încercări de a îmbunătăţi soluții gândite iniţial sub presiune. Nu este greșit să recunoști că ai greșit. „Greșeala recunoscută este pe jumătate iertată.” Mult mai grav este să persiști în greșeală. „Errare humanum est, perseverare autem diabolicum.”

Când eram student (la drept), am aflat de la colegii din Politehnică acest îndemn (parodiind celebrul vers coșbucian): „Nu cerceta aceste legi căci ești prea prost să le-nțelegi”. Acum mi se pare că el a devenit de o actualitate cruntă. Legiuitorul trebuie să coboare din turnul său de fildeș și să explice soluțiile pe care le adoptă.

Materialul a fost publicat în revista online a Facultății de Drept, $\underline{\text { AUBD - Forum Juridic nr. }}$ $\underline{1 / 2020 .}$ 